\title{
PENERAPAN MODEL PEMBELAJARAN KOOPERATIF TIPE JIGSAW UNTUK MENINGKATKAN HASIL BELAJAR IPS SISWA KELAS V SD NEGERI 4 TENGANAN SEMESTER II TAHUN PELAJARAN 2018/2019
}

\author{
I MADE ARTA \\ SD Negeri 4 Tenganan \\ e-mail : imadearta@gmail.com
}

\begin{abstract}
ABSTRAK
Penelitian ini bertujuan untuk memperbaiki proses pembelajaran untuk meningkatkan hasil belajar IPS melalui penerapan model pembelajaran kooperatif tipe jigsaw. Penelitian tindakan kelas ini dirancang dalam dua siklus. Setiap siklus dilaksanakan dalam empat tahapan yaitu : perencanaan, pelaksanaan, evaluasi dan refleksi. Cakupan materi yang dipelajari pada siklus I adalah perjuangan para pejuang pada penjajahan Belanda dan Jepang, dan siklus II peranan tokoh pejuang dalam persiapan kemerdekaan Indonesdia. Subyek penelitian ini adalah siswa kelas V SDN 4 Tenganan tahun pelajaran 2018/2019 dengan jumlah siswa 10 orang. Objek penelitian ini adalah peningkatan hasil belajar IPS . Data hasil belajar IPS dikumpulkan dengan menggunakan tes hasil belajar yang berjumlah 10 butir soal pilihan ganda. Kreteria keberhasilan tindakan jika rata-rata hasil belajar IPS siswa minimal 75 dengan ketuntasan klasikal minimal 80\%. Hasil penelitian tindakan kelas menunjukkan bahwa Penerapan Model Pembelajaran Kooperatif Tipe Jigsaw dapat meningkatkan hasil belajar IPS siswa kelas V SD Negeri 4 Tenganan Tahun Pelajaran 2018/2019. Rata-rata hasil belajar IPS dari siklus I sebesar 73,00 dan siklus II menjadi 84,00 dengan ketuntasan klasikal dari $70 \%$ di siklus I menjadi $90 \%$ di siklus II. Hasil penelitian ini menunjukkan bahwa terjadi peningkatan hasil belajar IPS sebesar 20,00\%..Diharapkan teman sejawat mau mencoba melakukan PTK dalam rangka perbaikan pembelajaran. Dalam pembelajaran di SD khususnya IPS, instansi berwenang seperti Dinas Pendidikan Kecamatan dan instansi lainnya diharapkan dapat menggunakan hasil penelitian ini dalam rangka pengembangan pembelajaran IPS di SD dengan penerapan model pembelajaran kooperatif tipe jigsaw.
\end{abstract}

Info Artikel :

Diterima :

30 Mei 2021

Diperbaiki :

5 Juni 2021

Disetujui :

10 Juni 2021

Kata Kunci:

Pembelajaran

Kooperatif Tipe

jigsaw dan Hasil

Belajar

\section{PENDAHULUAN}

Seorang guru profesional dituntut untuk memiliki berbagai kompetensi, seperti yang diamanatkan Undang-Undang RI No. 14 tahun 2005 tentang Guru dan Dosen, bahwa guru sebagai penggagas perubahan di tengah masyarakat, dituntut untuk menguasai komptensi pedagogik, kepribadian, sosial dan kompetensi profesional yang diperoleh melalui pendidikan profesi. Oleh karena itu seorang guru memikul tanggung jawab besar terhadap pembelajaran khususnya kepada peserta didik demi meningkatkan pengetahuan dan hasil pengalaman belajarnya. Sebagai agen pembelajaran guru tidak hanya bertugas sebagai pengajar dan pendidik saja, tetapi harus pula memiliki kemampuan dalam memilih metode pembelajaran yang paling akomodatif dan kondusif untuk siswa sehingga siswa dapat mengembangkan potensi yang dimilikinya secara efektif dan efesien.

Namun dalam kenyataannya guru seringkali mendapat kendala bagaimana memilih dan menggunakan metode dalam pembelajaran, metode dan strategi yang bagaimana yang paling 
tepat untuk membahas satu materi pembelajaran, atau metode apakah yang paling diminati oleh sebagian besar siswa, sehingga tercipta pembelajaran yang "PAIKEM GEMBROT" yaitu Pembelajaran yang Aktif, Inovatif, Kreatif, Edukatif, Menyenangkan, Gembira dan Berbobot. Tengah Dewa Putu (1995) menyatakan bahwa kualitas pendidikan ditentukan oleh berbagai faktor seperti kualitas sumber daya pendidikan, kualitas guru, dan pengelola pendidikan, kualitas pembelajaran, sistem ujiaan dan pengendalian mutu serta kemampuan menangani berbagai pengaruh lingkungan..

Purwanto (dalam Muhibbin Syah : 1997) menyatakan bahwa proses pembelajaran merupakan komponen yang perlu mendapat perhatian khusus, sebab dalam proses pembelajaran inilah dapat dibentuk prilaku belajar yang sangat mempengaruhi hasil belajar. Ini berarti peran guru dalam proses pembelajaran sangat setrategis, karena berkualitas tidaknya proses pembelajaran tergantung dari kualitas kompetensi profesional guru, yang dapat menentukan kompetensi out put atau lulusan sekolah. Dalam rangka meningkatkan mutu pendidikan diperlukan berbagai upaya aktif dari pendidik untuk mewujudkan pembelajaran yang efektif dan efesien. Proses pembelajaran di kelas akan berhasil jika dalam pelaksanaannya guru memahami dengan baik peran, metode, fungsi model-model pembelajaran. Disamping mengetahui hal-hal tersebut guru juga diharapkan mampu menerapkan berbagai metode ajar sehingga paradigma pengajaran dapat dirubah menjadi paradigma pembelajaran sebagai tuntutan peraturan yang dimuat dalam peraturan pemerintah.

Keterampilan yang mesti dikuasai guru dalam melaksanakan pembelajaran untuk disebut profesional, yaitu : (1) keterampilan bertanya, (2) keterampilan memberi penguatan, (3) keterampilan mengadakan variasi, (4) keterampilan menjelaskan, (5) keterampilan membuka dan menutup pelajaran, (6) keterampilan membimbing diskusi, dan (7) keterampilan mengelola kelas. Keterampilan-keterampilan ini berhubungaan dengan kemampuan guru untuk menguasai dasardasar pengetahuan yang dapat memudahkan mereka untuk melakukan persiapan dan pelaksanaan proses pembelajaran untuk memberikan dukungan terhadap cara berfikir siswa yang kreatif dan imajinatif (I G. A. K. Wardani dan Siti Julaeha, Modul IDIK 4307:1-30)

Bahwa ada kemungkinan kelemahan proses pembelajaran yang terjadi akibat ketidak tepatan menggunakan metode dan teknik-teknik dalam pembelajaran yang menyebabkan rendahnya hasil belajar siswa. Hal-hal lain yang juga menyebabkan rendahnya hasil belajar siswa adalah akibat rendahnya kemauan guru untuk menerapkan model dan strategi pembelajaran yang bisa membuat peserta didik aktif dalam belajar. Banyak guru lebih cendrung berperan sebagai penyampai materi ajar daripada sebagai seorang guru sejati yang seharusnya bertugas sebagai pendididk. Kondisi yang ada tentu banyak berpengaruh terhadap kemauan guru menyiapkan bahan yang lebih baik, serta kemauan guru untuk menerapkan metode-metode ajar yang didapat di bangku kuliah. Disamping itu, guru kurang berkeinginan untuk mengembangkan keterampilan mengajar yang dapat menarik perhatian siswa dan merangsang siswa untuk aktif dalam mengikuti proses pembelajaran. Penjabaran diatas menguraiakn hal-hal yang berkaitan dengan upaya meningkatkan hasil belajar dimana sebagai seorang guru perlu memahami metode-metode ajar, menguasai model-model pembelajaran, menguasai teori-teori belajar, penguasaan teknik-teknik tertentu .Apabila guru dapat menguasai berbagai model pembelajaran (multi metode) dan mampu menerapkan dalam proses pembelajaran niscaya hasil belajar peserta didik akan dapat mencapai sesuai dengan ketuntasan yang telah direncanakn oleh sekolah.

Demikian pula pada mata pelajaran IPS apabila guru mampu menerapkan multi metode dalam proses pembelajaran tentunya hasil belajar siswa tidak akan rendah. Dari observasi awal dilakukan ditemukan hasil belajar siswa kelas V SD Negeri 4 Tenganan Tahun Pelajaran 2018/2019 dalam pembelajaran IPS masih rendah. Berkaitan dengan masalah tersebut, ada beberapa faktor yang mengakibatkan hasil belajar siswa rendah. Faktor tersebut adalah pertama metode yang digunakan oleh guru masih konvensional. Artinya guru hanya menggunakan metode 
ceramah saja. Pada umumnya proses pembelajaran dengan metode ceramah sangat sulit ditinggalkan sehingga kurang melibatkan siswa karena hanya guru yang aktif, sehingga siswa hanya bisa menerima apa yang diberikan oleh gurunya. Memang secara umum metode ceramah tidaklah buruk. namun, apabila diterapkan secara monoton maka akan menimbulkan kejenuhan dalam diri siswa. Hal ini menyebabkan siswa kurang aktif serta akan mengakibatkan siswa sangat sulit mengembangkan ide-ide dan mengajukan pertanyaan. Semua itu akan berujung pada hasil belajar siswa yang menurun.

Faktor lain adalah kurangnya fasilitas belajar siswa seperti alat peraga yang kurang memadai, siswa pasif dalam proses pembelajaran. Jika fasilitas belajar siswa kurang, tentu guru kesulitan untuk menciptakan situasi belajar yang kondusif. Semua itu akan berimplikasi pada hasil belajar siswa yang rendah. Selain itu, kurangnya kemampuan guru memanfaatkan sarana dan prasarana belajar seperti penggunaan alat-alat elektronik, dan terbatasnya buku-buku penunjang, sehingga mengakibatkan sulit mengkondisikan siswa dalam proses pembelajaran. Ditambah juga lingkungan yang kurang mendukung sehingga minat siswa untuk belajar sangat rendah. Melihat permasalahan tersebut di atas, ada ketertarikan peneliti untuk mencari cara untuk memecahkan masalah. Ide peneliti dalam memecahkan masalah tersebut adalah dengan menerapkan Model Pembelajaran Kooperatif tipe Jigsaw. Model kooperatif sesungguhnya adalah sebuah model yang menekankan adanya diskusi pada siswa. Apabila siswa telah berdiskusi, maka secara otomatis siswa akan aktif di kelas. Dengan demikian diharapkan hasil belajar siswa dapat meningkat.

Memperhatikan hal tersebut maka peneliti berkeinginan mengadakan Penelitian Tindakan Kelas (PTK) dengan judul "Penerapan Model Pembelajaran Kooperatif Tipe Jigsaw untuk Meningkatkan Hasil Belajar IPS pada Siswa Kelas V SD Negeri 4 Tenganan". Dengan harapan siswa lebih mudah memahami materi yang disampaikan oleh guru dan mampu mengkonstruksikan materi tersebut.sehingga menciptakan suasana pembelajaran yang efektif, efisien, dan menggairahkan.

\section{METODE PENELITIAN}

Jenis penelitian yang dilakukan adalah penelitian tindakan kelas (Classroom Action Research) yang secara umum bertujuan meningkatkan dan memperbaiki kualitas proses pembelajaran di kelas tempat berlangsungnya penelitian. Tindakan yang dilakukan dalam penelitian ini adalah penerapan model pembelajaran kooperatif tipe jigsaw. Salah satu karakteristik dari penelitian tindakan adalah bersifat self-evaluatif yaitu kegiatan modifikasi praktis yang dilakukan secara terus menerus (Depdiknas, 2005). Peneliti belajar dari pengalaman , sehingga diperoleh suatu model pembelajaran yang benar-benar sesuai dengan kondisi sekolah atau sosial yang ada.

Penelitian ini dibagi dalam dua siklus dengan masing-masing siklus terdiri dari empat tahapan yaitu: 1) perencanaan, 2) tindakan, 3) observasi/evaluasi, dan 4) refleksi. Desain penelitian ini dapat digambarkan seperti Gambar 1. 


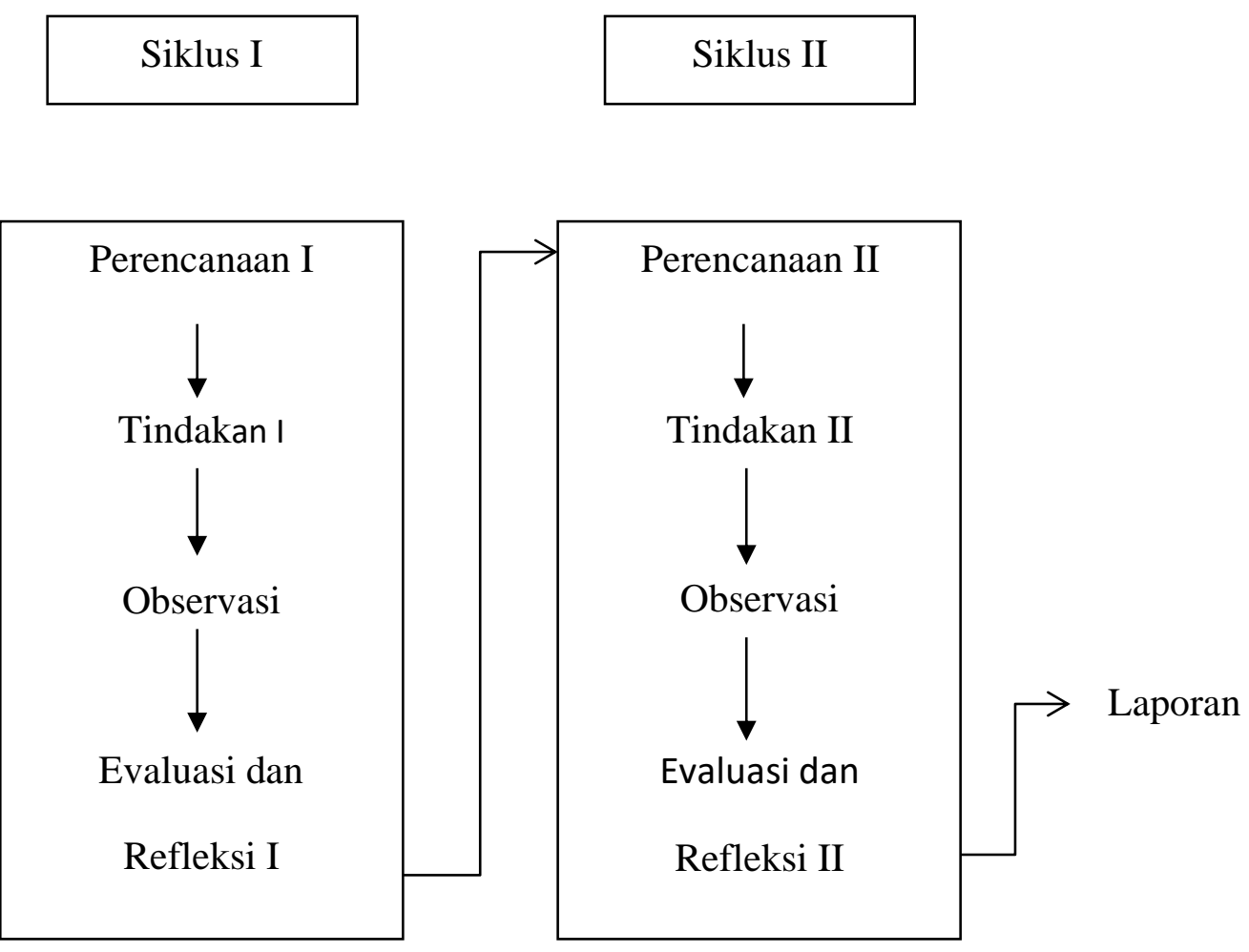

Gambar 1. Tahapan dalam Siklus Pembelajaran

\section{HASIL DAN PEMBAHASAN}

\section{Siklus I}

\section{Perencanaan Siklus I}

Tahap perencanaan peneliti menyusun proposal penelitian lengkap dengan Rencana Pelaksanaan Pembelajaran (RPP) yang akan dilaksanakan dengan penerapan model pembelajaran kooperatif tipe jigsaw. Berdasarkan hasil awal kemampuan siswa kelas V SD Negeri 4 Tenganan masih berada dibawah nilai ketuntasan minimal yang ditentukan sekolah, oleh karena itu peneliti merencanakan kegiatan yang lebih intensif seperti berkonsultasi dengan teman-teman guru dan kepala sekolah tentang persiapan pelaksanaan pembelajaran menggunakan pembelajaran kooperatif tipe jigsaw. Meminta teman guru mata pelajaran sejenis/rekan sejawat sebagai mitra kesejawatan dalam pelaksanaan pembelajaran yang sudah direncanakan. Hasilnya adalah kesiapan teman-teman guru untuk ikut melaksanakan supervisi kunjungan kelas dalam mengamati kekurangan yang ada.

Rekan sejawat juga berguna membantu dalam mengobservasi aktivitas belajar siswa, hal ini disebabkan oleh adanya keterbatasan peneliti dalam mengobservasi siswa yang jumlahnya cukup banyak serta menyusun instrumen penelitian yang meliputi tes hasil belajar dan lembar observasi. Peneliti merencanakan mengadakan penelitian di semester genap, sehingga mengadakan perencanaan di bulan Januarai 2019. Adapaun pelaksanaan kegiatan penelitian tindakan kelas siklus I ini akan dilakukan bulan Pebruari 2019. Pertemuan pertama akan dilakukan pada tanggal 4 Pebruari 2019, pertemuan kedua 11 Pebruari 2019, dan pertemuan ketiga 18 Pebruari 2019. 


\section{Pelaksanaan Siklus I}

Untuk menyelesaikan siklus I diperlukan 3 kali pertemuan dengan rincian 2 kali pertemuan untuk proses pembelajaran dan 1 kali pertemuan untuk pemberian tes akhir siklus. Pelaksanaan tindakan dilakukan oleh pengajar sendiri sekaligus sebagai peneliti dengan melibatkan 1(satu) orang teman sejawat yang diajak sebagai team teaching dan sekaligus sebagai observer. Peneliti dalam penelitian ini berperan sebagai guru yang mengimplementasikan model pembelajaran kooperatif tipe jigsaw. Guru menyampaikan secara singkat tentang model pembelajaran kooperatif tipe jigsaw yang dipakai sebagai alternatif model pembelajaran di kelas. Pembelajaran melalui pembelajaran kooperatif tipe jigsaw dimulai dari mengadakan eksplorasi yang bertujuan untuk menggali konsep awal siswa sebelum belajar. Pentingnya mengenal konsep awal siswa adalah sebagai pijakan awal untuk memulai pembelajaran. Adapun langkah-langkah yang dilakukan pada tahap pelaksanaan tindakan siklus I ini sebagai berikut.

1) Kegiatan Pendahuluan

a. Menyampaikan salam

b. Mengucapkan Panganjali "Om Swastyastu"

c. Mengecek kehadiran dan kesiapan siswa

d. Menyampaikan apersepsi

e. Menyampaikan indikator pembelajaran

f. Menyosialisasikan penerapan model Pembelajaran Kooperatif Tipe Jigsaw

2) Kegiatan Inti

a. Guru membagi siswa dalam dua kelompok (masing-masing kelompok beranggotakan lima orang)

b. Tiap siswa dalam kelompok diberi bahan materi yang berbeda (kelompok asal).

c. Tiap siswa dalam kelompok membaca dan mempelajari materi yang ditugaskan.

d. Anggota dari kelompok yang berbeda yang telah mempelajari materi yang sama bertemu dalam kelompok baru (kelompok ahli) untuk mendiskusikan bagian materi yang sama tersebut.

e. Setelah selesai diskusi dalam kelompok ahli, setiap siswa kembali ke kelompok asal.

f. Selanjutnya, mereka bergantian mengajar teman satu kelompok tentang materi yang telah ia pelajari/diskusikan dalam kelompok ahli. Sementara itu, anggota kelompok lainnya mendengarkan dengan sungguh-sungguh, kemudian membuat rangkuman.

g. Tiap kelompok mempresentasikan hasil diskusinya.

3) Kegiatan Penutup

a. Membuat simpulan/rangkuman

b. Melakukan evaluasi

c. Memberikan umpan balik

d. Salam penutup.

\section{Observasi/Evaluasi Data Hasil Penelitian Siklus I}

Observasi dilakukan ketika pembelajaran berlangsung untuk mengetahui aktivitas belajar siswa, sedangkan evaluasi dilaksanakan pada akhir siklus untuk mengetahui hasil belajar siswa. Hasil belajar IPS dikumpulkan dengan menggunakan tes hasil belajar yang berbentuk obyektif dengan jumlah 10 butir soal. Pada siklus I diberikan kepada 10 orang siswa kelas V sesuai dengan jumlah siswa di kelas tersebut .Rekapitulasi hasil tes hasil belajar siswa disajikan pada Tabel 1 berikut ini. 
Tabel 1. Rekapitulasi hasil tes hasil belajar" siklus I

\begin{tabular}{|c|c|c|c|c|c|c|c|c|c|c|c|c|c|}
\hline \multirow{2}{*}{ No } & \multicolumn{10}{|c|}{ Butir Soal } & \multirow{2}{*}{ Skor } & \multirow{2}{*}{ Nilai } & \multirow{2}{*}{ Keterangan } \\
\hline & 1 & 2 & 3 & 4 & 5 & 6 & 7 & 8 & 9 & 10 & & & \\
\hline 1 & 1 & 1 & 0 & 0 & 1 & 1 & 1 & 1 & 1 & 1 & 8 & 80 & Tuntas \\
\hline 2 & 1 & 0 & 1 & 0 & 1 & 0 & 1 & 1 & 1 & 0 & 6 & 60 & $\begin{array}{l}\text { Belum } \\
\text { Tuntas }\end{array}$ \\
\hline 3 & 0 & 1 & 1 & 0 & 1 & 1 & 1 & 1 & 1 & 1 & 8 & 80 & Tuntas \\
\hline 4 & 1 & 1 & 1 & 1 & 1 & 0 & 0 & 1 & 1 & 1 & 8 & 80 & Tuntas \\
\hline 5 & 0 & 0 & 1 & 0 & 1 & 0 & 0 & 1 & 1 & 1 & 5 & 50 & $\begin{array}{l}\text { Belum } \\
\text { Tuntas }\end{array}$ \\
\hline 6 & 1 & 1 & 1 & 1 & 0 & 1 & 1 & 0 & 1 & 1 & 8 & 80 & Tuntas \\
\hline 7 & 1 & 1 & 0 & 1 & 1 & 1 & 1 & 1 & 1 & 1 & 9 & 90 & Tuntas \\
\hline 8 & 1 & 1 & 1 & 1 & 1 & 1 & 1 & 1 & 0 & 0 & 8 & 80 & Tuntas \\
\hline 9 & 1 & 1 & 1 & 1 & 1 & 1 & 0 & 0 & 1 & 1 & 8 & 80 & Tuntas \\
\hline 10 & 1 & 0 & 0 & 1 & 1 & 1 & 1 & 0 & 0 & 0 & 5 & 50 & $\begin{array}{l}\text { Belum } \\
\text { Tuntas }\end{array}$ \\
\hline
\end{tabular}

Berdasarkan Tabel 1, hasil belajar" siswa kemudian dianalisis secara deskriftif untuk menentukan tingkat keberhasilan tindakan seperti Tabel 2.

Tabel 2. Hasil analisis hasil belajar" siklus I

\begin{tabular}{|l|l|l|}
\hline Aspek Analaisis & Hasil Perhitungan & Keterangan \\
\hline Skor Maksimum & 90 & \\
\hline Skor Minimum & 50 & \\
\hline Jumlah & 730 & \\
\hline Rata-rata & 73,00 & Belum Tuntas \\
\hline Daya Serap & $73,00 \%$ & Belum Tuntas \\
\hline Jumlah Siswa Yang Tuntas & 7 & \\
\hline Ketuntasan Belajar & $70 \%$ & Belum Tuntas \\
\hline
\end{tabular}

Pada siklus I rata-rata hasil belajar IPS siswa sebesar 73,00 dengan rentang skor 50 sampai dengan 90. Jumlah siswa yang tuntas sebanyak 7 orang siswa dengan presentase $70 \%$. Profil ketuntasan belajar siswa siklus I disajikan pada gambar 4.1 berikut ini. 


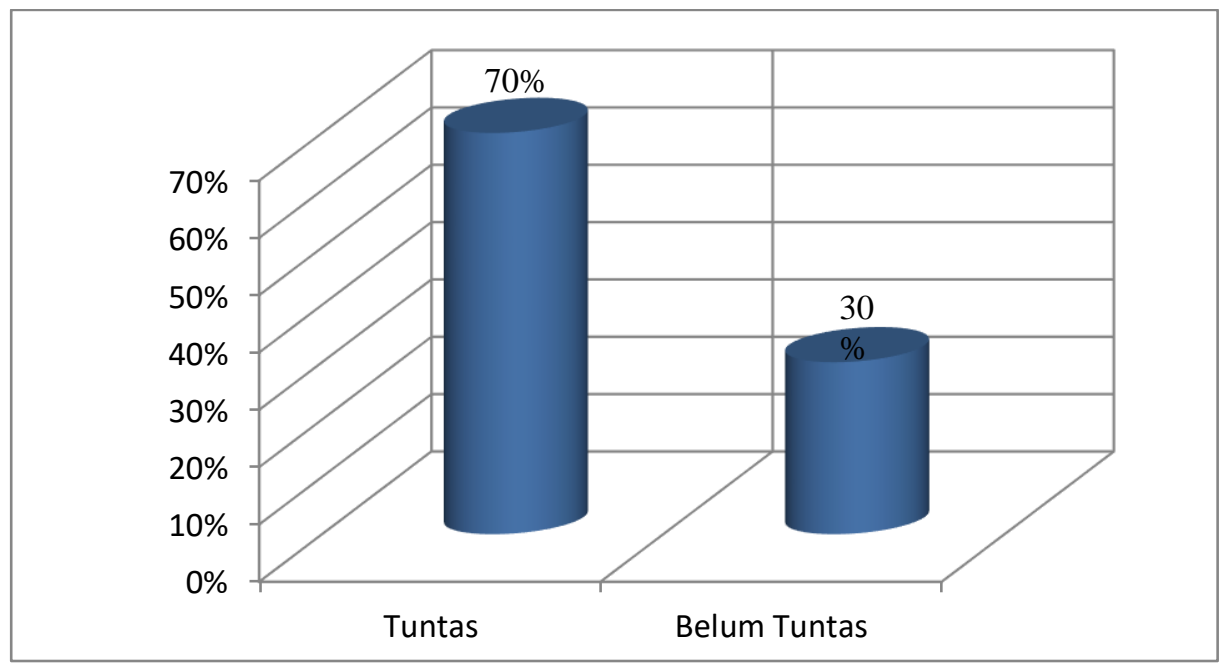

\section{Gambar 2. Grafik ketuntasan belajar siklus I}

Gambar 2. menunjukkan bahwa ketuntasan belajar siswa pada siklus I sebesar 70\%, masih ada $30 \%$ sekitar 3 orang siswa yang memiliki ketuntasan belajar dibawah ketuntasan minimal yang ditetapakan.

\section{Refleksi Siklus I}

Berdasarkan hasil di atas, nampaknya ketuntasan klasikal siswa baru mencapai $70 \%$ belum mencapai $80 \%$ atau seperti yang telah ditetapkan pada kreteria keberhasilan maka dilanjutkan ke siklus II. Pada refleksi siklus I ini, diperoleh hasil nilai rata-rata 70,00 dan daya serap 70,00\% sedangkan mengenai kelemahan dan keunggulan pelaksanaan tindakan pada siklus I adalah sebagai berikut.

Adapun kelemahan yang tampak dalam pelaksanaan penelitian tindakan kelas pada siklus I.

1) Siswa kurang memahami penjelasan guru mengenai pelaksanaan pembelajaran melalui Kooperatif Tipe Jigsaw karena metode ini betul-betul baru bagi siswa. Hal tersebut dapat diketahui dari tingkah laku siswa yang tampak bingung saat melaksanakan setiap tahap pada metode tersebut.

2) Saat penyajian hasil, kelompok lain masih disibukkan oleh aktivitas diskusi pada materi yang diperoleh sehingga tidak sempat mendengarkan sajian hasil diskusi kelompok yang presentasi.

3) Pemberian penghargaan atau penguatan kepada siswa yang aktif atau antusias masih minim.

4) Pemberian tugas rumah untuk persiapan pertemuan berikutnya belum dilakukan.

5) Daya ingat siswa terbatas, hanya mengingat materi saat dijelaskan. Ketika berselang beberapa hari, siswa lupa dengan materi tersebut karena siswa hanya menghafal tetapi tidak memahami/mendalami melalui pengalaman langsung.

Sementara itu, keunggulan yang tampak dalam pelaksanaan tindakan kelaspada siklus I.

1) Pembagian kelompok dilakukan secara merata dan adil, yakni dalam satu kelompok tersebut terdiri atas siswa dengan karakteristik kemampuan yang berbeda (pintar/mampu, sedang, dan kurang mampu), sehingga siswa yang kurang mampu dapat meminta penjelasan dari siswa yang mampu.

2) Pemberian umpan balik berupa pertanyaan-pertanyaan dapat mengasah kemampuan siswa pada setiap kelompok saat diskusi dilakukan. 
Berdasakan kelemahan dan keunggulan tersebut, yang perlu ditekankan dalam pembelajaran IPS pada siklus II sebagai berikut.

1) Mensosialisasikan langkah-langkah kegiatan pembelajaran dengan model Kooperatif Tipe Jigsaw secara jelas dan garis besarnya dituliskan secara singkat di papan untuk mengantisipasi siswa yang lupa.

2) Pemberian waktu yang jelas untuk kegiatan berdiskusi, sehingga harapannya ketika waktu yang ditentukan telah habis, seluruh kelompok tidak ada lagi yang berdiskusi. Semua kelompok terfokus pada penyajian hasil yang dilakukan oleh setiap kelompok secara bergiliran.

3) Pemberian penguatan/penghargaan kepada siswa yang aktif/antusias.

4) Pemberian tugas rumah untuk persiapan pembelajaran pada pertemuan berikutnya dan sekaligus untuk meningkatkan daya ingat siswa terhadap materi yang telah disampaikan dan materi yang akan dipelajari pertemuan berikutnya. Dengan demikian, pengetahuan yang diperoleh siswa akan melekat karena siswa dibiasakan mengulang kembali materi yang sudah dijelaskan melalui pengerjaan tugas rumah tersebut.

\section{Siklus II}

\section{Perencanaan Siklus II}

Peneliti berkolaborasi dengan rekan sejawat menentukan hasil belajar sesuai dengan materi pelajaran yang dikaji. Membuat rencana pembelajaran untuk siklus II, yang terdiri dari : rencana pelaksanaan pembelajaran dan lembar kerja siswa untuk membantu siswa dalam proses pembelajaran. Menyiapkan penghargaan bagi siswa yang menunjukkan peningkatan itikad belajar dan hasil belajar. Menyiapkan alat yang digunakan dalam pembelajaran. Peneliti berdiskusi dengan rekan sejawat sebagai observer pembelajaran mengenai teknis pelaksanaan pembelajaran di siklus II. Berdasarkan hasil diskusi disepakati bahwa pemberian LKS sehari sebelum pembelajaran dimulai untuk memberikan kesempatan kepada siswa untuk mempersiapakan diri. Untuk menyelesaikan siklus II diperlukan 3 kali pertemuan dengan skenario yang telah dipersiapkan. Pelaksanaan tindakan dilakukan oleh pengajar sendiri sekaligus sebagai peneliti dengan melibatkan 1 (satu) orang teman sejawat yang diajak sebagai team teaching yang berfungsi sebagai observer. Pertemuan pertama siklus II akan dilakukan pada tanggal 18 Maret 2019, pertemuan kedua 25 Maret 2019, dan pertemuan ketiga 1 April 2019.

\section{Pelaksanaan Siklus II}

Pelaksanaan tindakan siklus II peneliti menyampaikan hasil refleksi pada siklus I, selanjutnya melakukan beberapa tindakan perbaikan seperti yang telah diuraikan pada pembahasan hasil refleksi pada siklus I. Proses pembelajaran pada siklus II akan dilakukan dengan 3 kali pertemuan. Pertemuan pertama dan kedua adalah proses pembelajaran dan pertemuan ketiga adalah tes akhir siklus II. Pelaksanaan tindakan dilakukan oleh pengajar sendiri sekaligus sebagai peneliti dengan melibatkan 1(satu) orang teman sejawat yang diajak sebagai team teaching dan sekaligus sebagai observer. Peneliti dalam penelitian ini berperan sebagai guru yang mengimplementasikan pembelajaran kooperatif tipe jigsaw. Guru menyampaikan secara singkat tentang pembelajaran kooperatif tipe jigsaw yang dipakai sebagai alternatif model pembelajaran di kelas. Pada pelaksanaan siklus II ini guru lebih menekankan kelemahankelemahan yang terjadi pada siklus I untuk dilakukan perbaikan sehingga hasil belajar siswa di siklus II meningkat. Pembelajaran melalui pembelajaran kooperatif tipe jigsaw dimulai dari mengadakan eksplorasi yang bertujuan untuk menggali konsep awal siswa sebelum belajar. Pentingnya mengenal konsep awal siswa adalah sebagai pijakan awal untuk memulai pembelajaran. Adapun langkah-langkah yang dilakukan pada tahap pelaksanaan tindakan siklus II ini sebagai berikut. 


\section{1) Kegiatan Pendahuluan}
a. Menyampaikan salam
b. Mengucapkan Panganjali "Om Swastyastu"
c. Mengecek kehadiran dan kesiapan siswa
d. Menyampaikan apersepsi
e. Menyampaikan indikator pembelajaran
f. Menyosialisasikan penerapan model Pembelajaran Kooperatif Tipe Jigsaw

\section{2) Kegiatan Inti}

a. Guru membagi siswa dalam dua kelompok (masing-masing kelompok beranggotakan lima orang)

b. Tiap siswa dalam kelompok diberi bahan materi yang berbeda (kelompok asal).

c. Tiap siswa dalam kelompok membaca dan mempelajari materi yang ditugaskan.

d. Anggota dari kelompok yang berbeda yang telah mempelajari materi yang sama bertemu dalam kelompok baru (kelompok ahli) untuk mendiskusikan bagian materi yang sama tersebut.

e. Setelah selesai diskusi dalam kelompok ahli, setiap siswa kembali ke kelompok asal.

f. Selanjutnya, mereka bergantian mengajar teman satu kelompok tentang materi yang telah ia pelajari/diskusikan dalam kelompok ahli. Sementara itu, anggota kelompok lainnya mendengarkan dengan sungguh-sungguh, kemudian membuat rangkuman.

g. Tiap kelompok mempresentasikan hasil diskusinya.

\section{3) Kegiatan Penutup}
a. Membuat simpulan/rangkuman
b. Melakukan evaluasi
c. Memberikan umpan balik
d. Salam penutup

\section{Observasi/Evaluasi Data Hasil Penelitian Siklus II}

Observasi dilakukan ketika pembelajaran berlangsung untuk mengetahui aktivitas belajar siswa, sedangkan evaluasi dilaksanakan pada akhir siklus untuk mengetahui hasil belajar siswa. Hasil belajar IPS dikumpulkan dengan menggunakan tes hasil belajar" yang berbentuk obyektif dengan jumlah 10 butir soal. Pada siklus II diberikan kepada 14 orang siswa kelas V sesuai dengan jumlah siswa di kelas tersebut. Rekapitulasi hasil tes hasil belajar siswa disajikan pada Tabel 3 berikut ini.

Tabel 3 Rekapitulasi hasil tes hasil belajar siklus II

\begin{tabular}{|l|l|l|l|l|l|l|l|l|l|l|l|l|l|}
\hline \multirow{2}{*}{ No } & \multicolumn{10}{|c|}{ Butir Soal } & Skor & Nilai & $\begin{array}{l}\text { Ketera } \\
\text { ngan }\end{array}$ \\
\cline { 2 - 15 } & 1 & 2 & 3 & 4 & 5 & 6 & 7 & 8 & 9 & 10 & & & Tuntas \\
\hline 1 & 1 & 1 & 1 & 1 & 1 & 1 & 1 & 1 & 1 & 0 & 9 & 90 & Tuntas \\
\hline 2 & 0 & 1 & 1 & 1 & 0 & 1 & 1 & 1 & 1 & 1 & 8 & 80 & Tuntas \\
\hline 3 & 1 & 1 & 1 & 1 & 1 & 1 & 1 & 1 & 1 & 0 & 9 & 90 & Tuntas \\
\hline 4 & 1 & 1 & 1 & 1 & 0 & 1 & 1 & 1 & 1 & 1 & 9 & 90 & Tuntas \\
\hline 5 & 1 & 1 & 1 & 1 & 1 & 0 & 0 & 1 & 1 & 1 & 8 & 80 & Tuntas \\
\hline 6 & 0 & 1 & 1 & 1 & 1 & 1 & 1 & 1 & 1 & 1 & 9 & 90 & Tuntas \\
\hline 7 & 1 & 1 & 1 & 1 & 1 & 1 & 0 & 1 & 1 & 1 & 9 & 90 & \\
\hline
\end{tabular}




\begin{tabular}{|l|l|l|l|l|l|l|l|l|l|l|l|l|l|}
\hline 8 & 1 & 1 & 1 & 1 & 1 & 1 & 1 & 0 & 0 & 1 & 8 & 80 & Tuntas \\
\hline 9 & 1 & 1 & 1 & 1 & 1 & 1 & 1 & 0 & 1 & 0 & 8 & 80 & Tuntas \\
\hline 10 & 0 & 0 & 1 & 1 & 1 & 1 & 1 & 0 & 1 & 1 & 7 & 70 & $\begin{array}{l}\text { Belum } \\
\text { Tuntas }\end{array}$ \\
\hline
\end{tabular}

Berdasarkan Tabel 3, hasil belajar siswa kemudian dianalisis secara deskriftif untuk menentukan tingkat keberhasilan tindakan seperti Tabel 4.

Tabel 4. Hasil analisis hasil belajar siklus II

\begin{tabular}{|l|l|l|}
\hline Aspek Analaisis & Hasil Perhitungan & Keterangan \\
\hline Skor Maksimum & 90 & \\
\hline Skor Minimum & 70 & \\
\hline Jumlah & 840 & \\
\hline Rata-rata & 84,00 & Tuntas \\
\hline Daya Serap & $84,00 \%$ & Tuntas \\
\hline Jumlah Siswa Yang Tuntas & 9 & \\
\hline Ketuntasan Belajar & $90, \%$ & Tuntas \\
\hline
\end{tabular}

Pada siklus II rata-rata hasil belajar IPS siswa sebesar 84,00 dengan rentang skor 70 sampai dengan 90. Jumlah siswa yang tuntas sebanyak 9 orang siswa dengan presentase 90\%. Profil ketuntasan belajar siswa siklus II disajikan pada gambar 2 berikut ini.

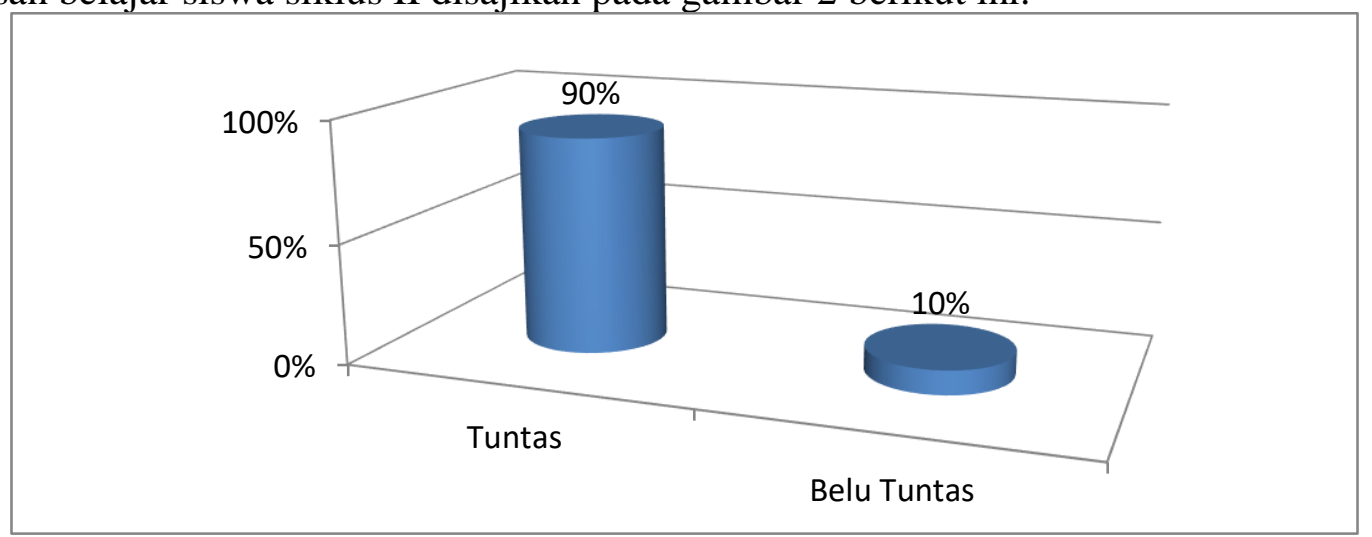

\section{Gambar 2. Grafik ketuntasan belajar siklus II}

Gambar 2 menunjukkan bahwa ketuntasan belajar siswa pada siklus II sebesar 90\%, masih ada $30 \%$ yaitu 1 orang siswa yang memiliki ketuntasan belajar dibawah ketuntasan minimal yang ditetapakan

\section{Hasil Refleksi Siklus II}

Adanya peningkatan persentase nilai siswa baik dari segi hasil belajar siswa menunjukkan bahwa kegiatan pembelajaran pada siklus II sudah berjalan dengan baik. Pendekatan dan bimbingan yang diberikan pada siswa membuat siswa lebih berani bertanya dan mengemukakan pendapatnya. Siswa juga sudah bisa menghargai setiap pendapat yang diajukan, hal ini dapat menghilangkan rasa takut dan malu siswa ketika ingin memberikan suatu pendapat. Aktivitas siswa ketika melakukan pembelajaran sudah mulai tampak baik dari segi kerja sama kelompok maupun dalam kegiatan diskusi kelas. Frekwensi siswa-siswa yang bercanda pada siklus II ini sudah senmakin berkurang. Meskipun masih terdapat beberapa siswa yang bercanda, namun hal 
tersebut sudah bisa diatasi oleh peneliti dan guru yaitu dengan mendatangi langsung siswa dan memberikan bimbingan secukupnya. Dominasi siswa-siswa yang pintar bekerja sendiri dalam kelompok juga sudah mulai berkurang. Siswa-siswa tersebut sudah mau memberi kesempatan kepada teman-teman dalam kelompoknya untuk melakukan pembelajaran, serta memberi penjelasan apabila rekannya tersebut mengalami kekeliruan. Hasil dari refleksi ini menunjukkan bahwa dengan perbaikan yang dilakukan terjadi peningkatan kualitas dari segi kegiatan proses belajar mengajar di kelas.

- Perbandingan Hasil Penelitian dan Kreteria Keberhasilan Penelitian

Perkembangan hasil penelitian antara siklus I dan siklus II dapat dilihat kembali pada hasil belajar siswa selama siklus I dan siklus II. Perbandingan nilai hasil belajar siswa antara siklus I dengan siklus II adalah sebagai berikut.

Tabel 5. Perbandingan hasil belajar IPS

\begin{tabular}{|l|l|l|l|l|}
\hline \multirow{2}{*}{ No } & \multicolumn{2}{|l|}{ Siklus I } & \multicolumn{2}{l|}{ Siklus II } \\
\cline { 2 - 5 } & Nilai & Ketuntasan & Nilai & Ketuntasan \\
\hline 1 & 80 & Ttuntas & 90 & Tuntas \\
\hline 2 & 60 & BelumTuntas & 80 & Tuntas \\
\hline 3 & 80 & Tuntas & 90 & Tuntas \\
\hline 4 & 80 & Tuntas & 90 & Tuntas \\
\hline 5 & 50 & Belum Tuntas & 80 & Tuntas \\
\hline 6 & 80 & Tuntas & 90 & Tuntas \\
\hline 7 & 90 & Tuntas & 90 & Tuntas \\
\hline 8 & 80 & Tuntas & 80 & Tuntas \\
\hline 9 & 80 & Tuntas & 80 & Tuntas \\
\hline 10 & 50 & BelumTuntas & 70 & BelumTuntas \\
\hline
\end{tabular}

Berdasarkan Tabel 2, akan ditentukan kreteria keberhasilan tindakan penelitian. Rekap perbandingan hasil analisis disajikan pada Tabel 4.

Tabel 6. Perbandingan aspek hasil belajar

\begin{tabular}{|l|l|l|l|l|}
\hline \multirow{2}{*}{$\begin{array}{l}\text { Aspek yang } \\
\text { dibandingkan }\end{array}$} & \multicolumn{2}{|l|}{ Siklus I } & \multicolumn{2}{l|}{ Siklus II } \\
\cline { 2 - 5 } & Nilai & Keterangan & Nilai & Keterangan \\
\hline Jumlah & 730 & & 840 & \\
\hline Rata-rata & 73,00 & Belum Tuntas & 84,00 & Tuntas \\
\hline Daya Serap & $73,00 \%$ & Belum Tuntas & $84,00 \%$ & Tuntas \\
\hline Ketuntasan & $70 \%$ & Belum Tuntas & $90 \%$ & Tuntas \\
\hline
\end{tabular}

Berdasarkan Tabel 6, tampak terjadi peningkatan rata-rata hasil belajar IPS dari siklus I sebesar 73,00 ke siklus II menjadi 84,00 dengan ketuntasan klasikal dari 70\% di siklus I menjadi 90\% di siklus II. Hasil penelitian ini menunjukkan bahwa terjadi peningkatan hasil belajar IPS sebesar 20\%. Oleh karena itu dapat disimpulkan bahwa penerapan model pembelajaran kooperatif tipe jigsaw dapat meningkatkan hasil belajar IPS siswa kelas V SD Negeri 4 Tenganan. Profil pencapaian hasil belajar dari masing-masing siklus disajiakn pada gamabar 4. 


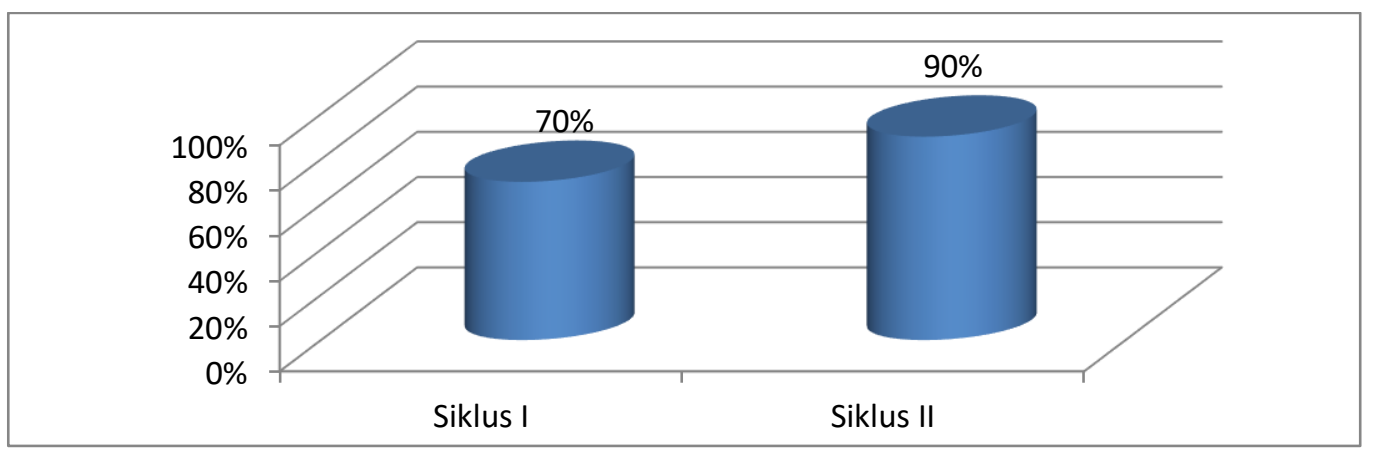

\section{Gambar 3. Grafik Profil hasil belajar" IPS siswa}

Berdasarkan hasil penelitian yang dilaksanakan dalam dua siklus, menunjukkan telah terjadi peningkatan hasil belajar IPS. Hasil belajar IPS meningkat sebesar $20 \%$ dari siklus I ke siklus II. Rata-rata hasil belajar IPS dari siklus I sebesar 73,00 ke siklus II menjadi 84,00 dengan ketuntasan klasikal dari 70\% di siklus I menjadi 90\% di siklus II. Peningkatan rata-rata, daya serap, dan ketuntasan klasikal dari siklus I sampai siklus II disebabkan karena pelaksanaan pembelajaran kooperatif tipe jigsaw pada siklus II lebih optimal. Hal ini terbukti dengan adanya perbaikan kelemahan-kelemahan yang peneliti temukan pada prasiklus dan pada siklus I. Melihat hasil penelitian ini, peneliti mengucapkan rasa syukur, karena walaupun kendala-kendala yang dirasakan sebelum dilaksanakan penelitian yang mengkhawatirkan kelancaran pelaksanaan penelitian, seperti kurangnya alat peraga. Namun berkat dari kemauan yang sungguh-sungguh dari peneliti/guru untuk memperbaiki hasil belajar IPS siswa dengan menerapkan pembelajaran kooperatif tipe jigsaw, dan atas dorongan dari kepala sekolah maka penelitian ini dapat dilaksanakan dengan lancar dari sejak awal sampai akhir sesuai dengan rencana.

Kemauan dan usaha yang dilakukan peneliti dalam penelitian ini dengan dipahaminya isi dan tuntutan Kurikulum Satuan Tingkat Pendidikan mata pelajaran IPS dan dimaknainya hasil refleksi tiap siklus sehingga hasil belajar"IPS yang dicapai dapat ditingkatkan. Dengan penerapan model pembelajaran kooperatif tipe jigsaw pembelajaran IPS berpusat pada siswa serta memberikan pengalaman langsung pada siswa untuk memproses perolehannya sehingga menjadi bermakna. Sesuatu yang bermakna baginya akan sulit untuk dilupakan.

Disamping itu pembelajaran IPS dengan pembelajaran kooperatif tipe jigsaw siswa lebih banyak melakukan diskusi dan tanya jawab serta dilengkapi dengan alat peraga sehingga materi pelajaran akan lebih mudah dikuasi. Hasil belajar yang diperoleh dengan bantuan alat peraga oleh anak SD akan sulit untuk dilupakan. Tampaknya inilah yang mendorong terjadinya peningkatan hasil belajar siswa dari siklus satu ke siklus dua karena apa yang mereka peroleh melalui alat peraga sehingga lama dapat diingat.

Hasil penelitian ini ternyata telah memberi efek yang positif bahwa model yang diterapkan dalam proses pembelajaran berpengaruh secara signifikan terhadap hasil belajar siswa. Temuan ini membuktikan bahwa guru sudah tepat memilih metode dalam melaksanakan proses pembelajaran, karena pemilihan metode tidak boleh dikesampingkan. Hal ini sejalan pula dengan temuan-temuan peneliti lain seperti yang dilakukan oleh Nyoman Dantes (2014) dalam penelitiannya yang berjudul Pengaruh Implementasi Model Pembelajaran Tipe Thing-Pair-Share (TPS) Terhadap Motivasi Belajar dan Prestasi Belajar Dalam Pembelajaran IPS Pada Peserta Didik Sekolah Dasar Gugus VIII Kecamatan Buleleng. Berdasarkan hasil penelitian tersebut menunjukkan bahwa penerapan pembelajaran kooperatif tipe TPS lebih baik dibanding pembelajaran konvensional.

Disamping itu aktivitas dan keaktifan siswa dalam mengikuti kegiatan pembelajaran mengalami peningkatan. Berdasarkan data awal sebelum dilakukan tindakan, presentase 
keaktifan siswa termasuk kategori kurang atau rendah, ini dilihat dari jumlah siswa yang aktif belajar belum maksimal, terbukti menurut catatan masih ada siswa yang mengobrol saat pembelajaran sedang berlangsung, terdapat siswa yang mengerjakan tugas mata pelajaran lain, dan masih ada siswa yang diam saja. Hal ini disebabkan oleh berbagai kendala atau permasalahan yang beragam diantaranya karakteristik siswa kelas $\mathrm{V}$ yang sulit dikendalikan, kurang tepatnya metode pembelajaran yang digunakan atau faktor yang lain yang mempengaruhi kurangnya aktivitas siswa, sehingga kegiatan pembelajaran yang seharusnya menjadi inti kegiatan banayak terganggu oleh masalah yang dihadapi oleh masing-masing siswa baik secara teknis maupun ada kegiatan pribadi yang tidak ada kaitannya dengan materi pembelajaran.

Observer atau pengamatan yang dilakukan oleh rekan guru yang bertindak sebagai observer menyatakan bahwa aktivitas guru sudah cukup bahkan baik, meskipun ada beberapa hal diperbaiki berkaitan dengan bagaimana menciptakan pembelajaran yang dapat meningkatkan aktivitas dan hasil belajar siswa. Hal ini dipandang sesuai dimana aktivitas guru banyak berfungsi sebagai pasilitator dan motivator yang melayani siswa, baik dalam menguasai materi pembelajaran maupun dalam meningkatkan kualitas belajar siswa.

Jadi penggunaan model pembelajaran kooperatif tipe jigsaw dalam pembelajaran IPS di kelas V SD Negeri 4 Tenganan dapat meningkatkan hasil belajar IPS siswa. Peningkatan hasil belajar ini tidak lepas dari usaha peneliti untuk memperbaiki proses pembelajaran dengan memusatkan kegiatan pembelajaran pada siswa melalui kerja kelompok kecil yang dilengkapi dengan LKS. Jadi jika pembelajaran IPS di SD dilakukan dengan menggunakan model pembelajaran kooperatif tipe jigsaw yang dilengkapi dengan LKS dan sarana yang diperlukan maka kegiatan pembelajaran IPS akan berpusat pada siswa, menyenangkan dan bermakna.

\section{KESIMPULAN}

Berdasarkan hasil dari penelitian di atas, dapat disimpulkan bahwa penerapan model pembelajaran Kooperatif tipe jigsaw dapat meningkatkan hasil belajar siswa kelas V SD Negeri 4 Tenganan tahun pelajaran 2018/2019. Hal ini terbukti dari rata-rata hasil belajar IPS dari siklus I sebesar 73,00 ke siklus II menjadi 84,00 dengan ketuntasan klasikal dari 70\% di siklus I menjadi $90 \%$ di siklus II. Hasil penelitian ini menunjukkan bahwa terjadi peningkatan hasil belajar IPS sebesar $20 \%$.

\section{DAFTAR PUSTAKA}

Arikunto, Suharsimi. (2002). Penelitian Tindakan Kelas. Jakarta : Bumi aksara

Chotimah, H. \& Dwitasari, Y. (2009). Strategi Pembelajaran Untuk Penelitian Tindakan Kelas. Malang : Surya Pena Gemilang Publishing.

Dantes, N. (2001). Cara Pengajuan Alat Ukur. Singaraja : IKIP Negeri Singaraja.

Dantes, Nyoman. Dkk (2014) . Pengaruh Implementasi Model Pembelajaran Kooperatif Tipe Thing-Pair-Share (TPS) Terhadap Motivasi Belajar dan Hasil belajar" dalam Pembelajaran IPS Pada Siswa Kelas V Sekolah Dasar Gugus VIII Kecamatan Buleleng. E-Journal Program Pascasarjana Uiversitas Ganesha. Vol 1 Tahun 2014

Departemen Pendidikan Nasional, 1998, Kamus Besar Bahasa Indonesia,Jakarta.

Departemen Agama. (2004). Standar Kompetensi Madrasah Iptitadiah. Jakarta : Direktorat Jendral Kelembagaan Agama Islam.

Depdiknas. (2005). Pendidikan Kewarganegaraan, Strategi dan Metode Pembelajaran Pendidikan Kewarganegaraan. Jakarta : Depdiknas

Gagne, Robert M. (1997). Condition of Learning Third Edition. New York : Holt, Reinhart and Winston.

Hamalik, Oemar. (2002). Psikologi Belajar dan Mengajar. Bandung : Sinar Baru.

Isjoni. (2007). Cooperative Learning Efektifitas Pembelajaran Kelompok. Alfabeta Bandung. 
Johnson DW Johnson ,RT. (1991). Learning Togather and Alone. Allinand Bacon Massa Chussettes.

Kasim, Melany. (2008). IPS (online), Http//wodpress . com. ( diakses 20 April 2009).

Komalasari, K. (2009). Pembelajaran Kontekstual Konsep dan Aplikasi. Bandung: Refika Aditama.

Lasmawan. (2001). Pengelolaan dan Operasionalisasi Pembelajaran IPS di Sekolah Dasar. (Makalah) Program Pasca Sarjana IKIP Bandung.

Lasmawan,Wayan. Dkk (2014). Pengaruh Pendekatan Pembelajaran Kontekstual Terhadap Sikap Sosial dan Hasil Belajar dalam Pembelajaran IPS kelas V SD Negeri Gugus Singekerta Kecamatan Ubud Kabupaten Gianyar. E-Jurnal Program Pasca Sarjana (Volume 4 Tahun 2014)

Muhibbin Syah. (1997). Psikologi Pendidikan dengan Pendekatan Baru. Bandung: PT.Remaja Rosdakarya.

Nurkancana dan Sumartana. (2004). Evaluasi Pendidikan. Surabaya : Usaha Nasional.

Nursid Sumaatmadja, (2006). Konsep Dasar IPS. Jakarta : UT.

Rusman. (2011). Model-Model Pembelajaran, Mengembangkan Profesionalisme Guru. Rajawali Pers : Jakarta.

Sapriya, et al. (2007). Konsep Dasar IPS. Bandung : Laboratorium Pendidikan.

Slameto. (2003). Belajar dan Faktor-faktor yang Mempengaruhinya. Jakarta : Renika

Slavin, Robert E. (2005). Cooperative Learning (cara efektif pada prestasi seluruh Peserta didik) Bandung : Nusa Media.

Solihatin, Etin dan Raharjo. (2007). Cooperatve Learning Analisis Pembelajaran IPS. Bumi Aksara : Jakarta

Sudjana. (2004). Statistik Pendidikan. Jakarata : PT Raja Grasindo Persada

Sugianto. (2010). Model-model Pembelajaran Inovatif. Surakarta : Yuma Pustaka.

Suprijono, Agus. (2010). Cooperative Learning Teori \& Aplikasi Paikem. Jogjakarta: Pustaka Pelajar

Susani, Ketut. (2014). Pengaruh Pembelajaran Team Quiz Terhadap Hasil Belajar,IPS Dari Sikap Sosial Siswa Kelas VI Kuta Utara. E- Jurnal Program SarjanaUniversitas Ganesha. (Volume 4 Tahun 2014)

Tengah Dewa Putu. (1995). Masalah dan Tantangannya Pendidikan Abad 21. Makalah disampaikan pada Seminar Guru dan Pendidikan Guru di Kampus STKIP Negeri Singaraja 17 Nopember 1995.

Tranto. (2010). Mendesain Model Pembelajaran Inovatif-Progresif, Konsep, Landasan, dan Implikasinya Pada Kurikulum Tingkat Satuan Pendidikan (KTSP).Kencana : Jakarta.

Wahidmuni. (2010). Pengembangan Kurikulum IPS dan Ekonomi di Sekolah Madrasah.Malang : UIN Maliki Press.

Wardani, I.G.A. K Siti Julaeha. Modul IDIK 4307. Pemantapan Kemampuan Mengajar.Jakarta : Universitas Terbuka.

Yaba. (2006). Ilmu Pengetahuan Sosial 1. Program Studi Pendidikan Guru sekolah Dasar. Fakultas Ilmu Pendidikan Universitas Negeri Makasar Makasar.

Zaini, Hasym dkk. (2008). Strategi Pembelajaran Aktif. Yogyakarta : Pustaka Insan Mandiri. 